\title{
Perspektif Al-Quran Tentang Prinsip-Prinsip Konsumsi
}

\author{
Desri Nengsih *) \\ Institut Agama Islam \\ Negeri Bukittinggi, \\ Sumatera Barat, Indonesia \\ Email: \\ edesrinengsih@gmail.com
}

\section{Sefri Auliya}

Universitas Islam Negeri Imam Bonjol Padang, Sumatera Barat, Indonesia Email:

archelazizah@gmail.com

*) Corresponding Author

\begin{abstract}
Abstrak: Tulisan ini mengkaji tentang prinsip-prinsip konsumsi dalam Alquran dengan melakukan analisa terhadap ayat-ayat Alquran yang mengandung unsur-unsur konsumsi. Penelitian ini merupakan penelitian kualitatif dengan pendekatan tafsir tematik. Adapun sumber utama penelitian ini adalah ayat-ayat Alquran yang mengandung unsur prinsip-prinsip konsumsi. Sebagai sumber pendukung digunakan juga kitab-kitab tafsir dan literatur-literatur lainnya yang terkait dengan pokok bahasan. Dari penelitian ini secara umum ditemukan empat dasar prinsip konsumsi dalam Alquran, yaitu memperhatikan aspek kualitas makanan (halal lagi baik), tidak berlebihan dalam mengkonsumsi hanya sebatas sesuai kebutuhan, tidak boros dan jauh dari prilaku mubazir, dan tidak pelit mesti seimbang dan sederhana dalam konsumsi.
\end{abstract}

\begin{abstract}
This paper examines the principles of consumption in the Quran by analyzing the verses of the Quran that contain elements of consumption. This research is a qualitative research with a thematic interpretation approach. The main source of this research is the Qur'anic verses which contain elements of consumption principles. As a supporting source also used books of commentary and other literature related to the subject. From this research generally found four basic principles of consumption in the Quran, namely paying attention to aspects of food quality (halal again good), not excessive in consuming only as needed, not wasteful and far from wasteful behavior, and not stingy must be balanced and simple.
\end{abstract}

Kata Kunci: Konsumsi, Alquran, Ayat Ekonomi

\section{PENDAHULUAN}

Alquran sudah

memberikan

petunjuk yang jelas tentang semua urusan manusia, sehingga, ayat-ayat Alquran perlu ditafsirkan untuk menghasilkan pemahaman yang tepat tentang prilaku kehidupan manusia, termasuk dalam bidang perekonomian, karena pengembangan ilmu ekonomi Islam yang bersumber dari Alquran mempunyai peluang yang sama dengan pengembangan keilmuan lainnya. Sebagai sebuah metodologi, tafsir ekonomi terhadap ayat-ayat Alquran memberi peluang bagi pengembangan ilmu ekonomi Islam (Kasdi, 2013). Hal ini disebabkan karena setiap manusia selalu melakukan aktivitas perekonomian, terutama aktivitas konsumsi yang tidak akan pernah lepas dari kehidupan sehari-hari. Manusia membutuhkan berbagai konsumsi untuk dapat mempertahankan hidupnya. Karena itu, perlu dilakukan penafsiran terhadap ayat-ayat yang 
berkaitan tentang perihal konsumsi, kepada Allah Swt. untuk mendapatkan sehingga didapatkan suatu pemahaman kemenangan, kedamaian dan yang proporsional terhadap prinsip- kesejahteraan akhirat, baik dengan prinsip konsumsi dalam Alquran. membelanjakan hartanya untuk

Menurut Suherman Rosyidi yang keperluan dirinya sendiri ataupun dikutip oleh Idri mengatakan, "Secara untuk amal sholeh, yang tidak hanya sederhana, konsumsi dalam ilmu terfokus pada penghabisan barang ekonomi diartikan sebagai pemakaian semata dan pemuasan keinginan atau barang untuk mencukupi suatu kebutuhan.

kebutuhan secara langsung. Selain itu, Berdasarkan petunjuk Alquran, konsumsi juga diartikan dengan Islam memberikan rambu-rambu yang penggunaan barang dan jasa untuk terukur agar tujuan konsumsi dapat memuaskan kebutuhan manusiawi. tercapai, yaitu kesejahteraan hidup di (Idri, 2016: 98). Maka, istilah dunia dan akhirat dapat diwujudkan. konsumsi yang dimaksud dalam tulisan Apalagi kebutuhan manusia yang terus ini bukan semata-mata makan dan berkembang seiring dengan minum saja, namun mencakup segala meningkatnya pola dan gaya hidup. bentuk pemakaian dan pemanfaatan (Kementrian Agama RI, 2009: 223) barang dan jasa untuk memenuhi Keinginan manusia untuk kebutuhan manusia dalam kehidupan memenuhi kebutuhannya tidak ada sehari-hari.

batasnya, kecuali mereka sendiri

Jika dilihat dalam perspektif mampu mengendalikan diri dan konvensional, aktivitas konsumsi menyadari bahwa ada akhirat sebagai sangat erat kaitannya dengan tempat kembali yang kekal. Bahkan, maksimalisasi kepuasan (utility). Tentu Rasulullah Saw. sendiri tidak saja hal ini bertentangan dengan apa menafikan adanya kemungkinan yang disebutkan dalam Alquran, karena perbuatan manusia seperti ini, seperti aktivitas konsumsi dalam Islam disebutkan dalam sabdanya:“ merupakan salah satu aktivitas "Seandainya seorang manusia ekonomi manusia yang bertujuan untuk mempunyai harta sebanyak dua meningkatkan ibadah dan keimanan lembah, niscaya ia akan mencari 
lembah yang ketiga dan tidak akan penuh mulut manusia itu kecuali dengan tanah (kematian) dan Allah akan mengampuni orang yang bertaubat." (HR. Bukhari dan Muslim)

Berdasarkan data dan fakta di atas, maka konsumsi dalam Islam tidak dapat dipisahkan dari peranan keimanan. Kekuatan iman menjadi tolak ukur penting dalam memberikan cara pandang terhadap dunia yang cenderung mempengaruhi kepribadian manusia, serta tentunya sangat mempengaruhi kuantitas dan kualitas konsumsi, baik dalam bentuk kepuasan material maupun spiritual. Oleh sebab itu, perlu dilakukan kajian terstruktur tentang konsumsi dalam perspektif Alquran, khususnya terhadap ayat-ayat Alquran yang mengandung prinsipprinsip konsumsi supaya tercapai pola konsumsi yang seimbang antara kebutuhan dunia dan akhirat.

\section{METODE}

Penelitian ini merupakan penelitian kualitatif dengan pendekatan tafsir tematik. Disebut kualitatif karena prosedur penelitiannya menghasilkan data deskriptif berupa kata-kata dan catatan-catatan yang berhubungan langsung dengan makna dan pengertian. Pendekatan tafsir tematik dipilih karena relevan dengan pembahasan dan dinilai representatif, kemudian juga fokus mengkaji sebuah tema dari berbagai tema Alquran. Adapun data primer dalam penelitian ini adalah ayat-ayat Alquran yang berkenaan dengan prinsip-prinsip konsumsi. Sedangkan, data sekundernya adalah kitab-kitab tafsir dan beberapa literatur lain yang terkait dengan tema yang dibahas.

\section{HASIL DAN PEMBAHASAN}

Allah Swt. telah memberikan gambaran detail tentang prinsip-prinsip dasar konsumsi dalam Alquran. Tugas manusia adalah menyikapi aturan tersebut dengan penuh kehambaan, sehingga bukan hanya menjadi teks bisu yang hampa makna, tetapi teraplikasikan dalam kehidupan nyata. Dalam perkembangannya banyak pola yang digunakan oleh para ahli untuk merumuskan cara Allah Swt. menyampaikan pesan tentang bagaimana pola konsumsi yang sesuai dengan syari'at Islam. Salah satunya adalah membagi ayat-ayat konsumsi dalam Alquran berdasarkan kata kunci dan kandungan maknanya ke dalam 
dua kategori, yaitu periode Mekah dan periode Madinah.

Ayat-ayat konsumsi periode Mekah, yaitu surat al-Mursalât/77: 43 dan 46, al-A'râf/7: 31 dan 33, alFurqân/25: 7-8, 20, dan 67, Thâha/20: 81, asy-Syu'arâ'/26: 79, al-Isrâ'/17: 16, 26-29, Yûsuf /12: 47-48, al-Hijr/15: 3, al-An'âm/6: 118-121 dan 141-142, anNahl/16: 69 dan 114-115, alMu'minûn/23: 51, dan al-Mulk/67: 15. Sementara, ayat-ayat konsumsi periode Madinah, yaitu surat al-Baqarah/2: 5758, 60-61, 172-173 dan 168, anNisâ'/4: 6, 10, dan 29, al-Mâ'idah/5: 3, 88, dan 96, dan at-Tawbah/9: 34. (Syaparuddin, 2011). Akan tetapi, tidak semua ayat yang disebutkan di atas dibahas dalam tulisan ini karena hanya difokuskan pada prinsip-prinsip konsumsi dalam surat al-Baqarah/2: 168, al-A'râf/7: 31, al-Furqân/25: 67, dan al-Isrâ'/17: 26-27.

\section{Perhatian Terhadap Kualitas Dalam} Konsumsi

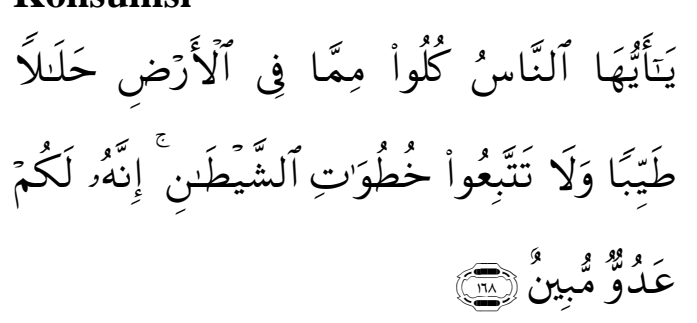

"Hai sekalian manusia, makanlah yang halal lagi baik dari apa yang terdapat di bumi, dan janganlah kamu mengikuti langkah-langkah syaitan; karena Sesungguhnya syaitan itu adalah musuh yang nyata bagimu." (QS. al-Baqarah:168)

Kata kunci konsumsi dalam ayat ini ditunjukkan dengan lafazh kulû yang berasal dari kata akala-ya'kulu yang berarti makan. Ayat ini diturunkan terhadap kaum Bani Tsaqif, Bani Khuza'ah, Bani 'Amir bin Sha'sha'ah, dan Bani Mudlij yang mengharamkan terhadap dirinya binatang-binatang yang dihalalkan dari sawâ'ib (hewan unta saibah), washâil (hewan unta wasilah), bahâir (hewan unta bahirah). (al-Qurthubiy, 2006: 3/11, ar-Raziy, 1981: 5/2, Ibn Katsir, 1999: 1/478)

Ayat ini menunjukkan tentang kasih sayang Allah terhadap hambaNya bahwa Ia adalah Maha Pemberi rezeki bagi semua makhluknya, yang membolehkan bagi semua manusia untuk mengkonsumsi semua yang ada di bumi selama halal lagi baik, yakni baik bagi diri mereka dan tidak menimbulkan mudharat terhadap badan dan akal. Di samping itu, Allah juga melarang manusia untuk mengikuti lagkah-langkah setan, yaitu jalannya setan untuk menyesatkan orang yang mengikutinya dengan cara 
mengharamkan yang dihalalkan oleh Allah Swt.

Kata الناس dalam ayat ini mencakup manusia secara keseluruhan tanpa membeda-bedakan suku, bangsa, etnik, bahkan agama sekalipun. Sedangkan, kata كلوا (makanlah) merupakan sinonim dari kata الإتتفاع, maksudnya adalah pemakaian, pemanfaatan atau pengunaan.

Dikatakan juga yang dimaksud dengan makan di sini adalah makanan yang mentradisi (al-akl al-mu'tad), atau alintifâ' lebih umum dari pada kata alakl yang kelihatan lebih khusus (spesifik), sebab makan adalah sebagian dari manfaat, sementara manfaat belum tentu atau tidak selalu dalam bentuk makan, mengingat ada juga manfaat lain yang tidak dalam bentuk makan, seperti tempat tinggal, pakaian, kendaraan, dan lain sebagainya. Dapat disimpulkan bahwa yang dimaksud dengan al-akl di sini adalah mendayagunakan harta (infâq al-mâl), karena makan (konsumsi) merupakan kebutuhan yang paling besar dan mendasar jika dibandingkan dengan kebutuhan-kebutuhan primer lainnya. (Muhammad Amin Suma, 2013: 110) yaitu sesuatu yang halal الحل lagi baik. Halal berasal dari kata yang berarti yang sudah terlepas dari larangan dan merupakan lawan dari kata عقد yang berarti terikat. Sedangkan pada dasarnya adalah sesuatu yang mengandung selera dan dianggap baik serta mensifatinya dengan kata thâhir (suci) dan halal secara bersamaan itu merupakan salah satu bentuk tasybih, karena setiap yang bernajis tidak disukai oleh jiwa, dan yang harampun tidak akan menjadi menarik, karena itulah syari'at melarangnya. (ar-Raziy, 1981: 5/3)

Adapun yang dimaksud dengan kata thayyib dalam ayat di atas dapat ditinjau dari dua perspektif; Pertama, bermakna mustaladz (sesuatu yang nikmat), karena kalau kita golongkan sesuatu yang nikmat terhadap yang halal pasti akan berulang. Dengan demikian hanya bisa dicapai dengan sesuatu yang thayyib (baik). Apabila dari segi jenisnya dia termasuk sesuatu yang mengundang selera, maka sesungguhnya mengkonsumsi sesuatu yang tidak mengundang selera padanya bisa kembali menjadi haram. Kedua, bermakna mubah (sesuatu yang dibolehkan). Imam ar-Raziy 49 
mengatakan, "Kami tidak bisa perut bumi. Hanya saja, demi kebaikan menerima pendapat yang mengatakan (kesehatan dan kemaslahatan) manusia setiap yang halal itu berulang-ulang, itu sendiri, Alquran memberikan karena حلالitu adalah jenisnya yang catatan bahwa meskipun secara umum halal dan thayyib itu adalah sesuatu boleh dikonsumsi, namun pada saat yang tidak berkaitan dengan hak orang yang bersamaan Allah memberikan lain. Jika seseorang mengkonsumsi catatan bahwa yang boleh dikonsumsi yang haram meskipun dianggap enak hanyalah yang halal lagi baik (halâlan atau mengundang selera untuk dimakan thayyiban). Sedangkan, barang-barang dari segi konsekuensi yang akan ekonomi terutama makanan dan didapat memakan yang haram itu akan minuman yang mengandung keburukan menjadi mudharat, sehingga tidak (khobâits) diharamkan untuk menjadi baik. (ar-Raziy, 1981: 5/3). dikonsumsi. (Muhammad Amin Suma, Menurut Mahmud al-Babili yang dikutip oleh Idri, "Pengaitan kata thayyib dan halal dalam ayat di atas mengandung tuntutan kepada kewajiban untuk menjauhi cara-cara yang tidak halal dalam memperoleh makanan dan minuman yang baik dan bersih atau menggunakannya pada halhal yang haram atau bisa menimbulkan keharaman. (Idri, 2016: 117)

Secara umum, ayat di atas atau beberapa ayat lain yang senada, pada prinsipnya memberikan keleluasaan dalam arti mempersilakan manusia untuk mengkonsumsi (makan, minum, memakai, menggunakan, berkendaraan, dan lain-lain) barang-barang ekonomi yang ada di permukaan maupun di 2013:112)

Setelah mempersilahkan manusia mengkonsumsi barang-barang ekonomi yang halâlan thayyiban, ayat di atas juga mengingatkan semua manusia (siapa, kapan, dan dimanapun) untuk tidak mengikuti ajakan, bujukan dan rayuan setan yang suka menggoda dan mendorong manusia untuk mengkonsumsi barang ekonomi tanpa mempedulikan antara yang halal dan haram, antara yang haq dan batil, serta antara yang baik dengan yang buruk. Karena karakternya yang buruk itulah Alquran selalu mengingatkan bahwa setan adalah musuh yang nyata bagi manusia, termasuk dalam melaksanakan tugas-tugas dalam dunia 
ekonomi dan keuangan, baik secara luas (usaha ekonomi) maupun yang spesifik (mengkonsumsi barang-barang ekonomi). (Muhammad Amin Suma, 2013:112-113)

Dari hal ini disimpulkan bahwa Allah secara tegas memerintahkan untuk mengkonsumsi suatu kebutuhan yang halal dan baik. Syaparuddin menyebutkan bahwa halal dan baik meliputi dua makna, yaitu: substansi dan proses substansi. Subtansi, maksudnya adalah sesuatu itu diperbolehkan Allah atau ada ketentuan hukum yang membolehkannya, yang mengangkat status hukum setiap perbuatan manusia, baik terhadap Allah, atau pun terhadap manusia itu dengan cara yang sah. Sedangkan proses subtansi adalah cara mencari, menggunakan, serta akibatnya tidak merugikan manusia di dunia dan di akherat. Artinya, barang atau uang yang diperoleh dengan cara, misalnya, mencuri, menyuap, dan menggelapkan barang, meskipun benda tersebut layak dan halal namun sifatnya adalah haram, maka orang yang melakukannya harus bertanggung jawab di dunia dan di akherat. (Syaparuddin, 2011: 366). Selanjutnya ia juga menjelaskan bahwa mengonsumsi suatu kebutuhan yang halal dan baik akan berpengaruh terhadap kehidupan umat Islam dalam menjalankan hukum-hukum Allah dan menyampaikan sunah Rasul, demikian juga akan berpengaruh terhadap perilaku mereka selanjutnya. Jika seseorang mengonsumsi suatu kebutuhan yang halal dan baik maka dengan sendirinya ia akan selalu condong kepada perbuatan baik pula. Sebaliknya jika ia mengonsumsi suatu kebutuhan yang buruk dan keji, maka ia akan selalu condong kepada perbuatan buruk dan keji pula (Syaparuddin, 2011).

Berdasarkan hal di atas, maka sesuatu yang boleh dikonsumsi adalah sesuatu yang halal, maka umat Islam harus menjalankan usaha-usaha yang halal (permissible conduct), jauh dari unsur perjudian dan penipuan; meliputi bahan baku, proses produksi, manajemen, output produksi hingga proses distribusi, dan konsumsi harus dalam kerangka halal. (Ruslan, 2014: 53). Di samping itu, juga harus memperhatikan baik atau tidaknya barang itu dikonsumsi yang diungkapkan Alquran dengan kata Thayyib. Selanjutnya Ruslan 
menyebutkan bahwa, "Ketika kata pengolahan menjadi dopamin, tapi juga thayyib ini dihubungkan dengan tidak banyak minum VCO karena bisa makanan maka segala makanan yang mengakibatkan law protein. Kriteria boleh dikonsumsi, baik dilihat dari segi kedua ini tentu agak sulit karena kadar (komposisi kandungannya) atau tempatnya, bahkan masanya (waktu kadaluarsanya). (Ruslan, 2014: 53) Selanjutnya ia menjelaskan bahwa ada empat hal yang perlu diperhatikan sebagai persyaratan makanan itu baik atau layak dikonsumsi; pertama, makanan tersebut harus halal. Ibn ولا تكسبوا المال الحرام Asyur menfasirkan (jangan berusaha harta haram). Usaha yang hasilnya haram dimakan seperti uang hasil pelacuran, perjudian, korupsi, dan mencuri. Sedangkan makanan yang zatnya itu sendiri diharamkan seperti daging babi, bangkai, darah, dan sebagainya. Kedua, kadar nutrisinya. Apakah kadar nutrisinya cocok buat seseorang atau tidak. Bagi yang hasil cek laboratorium kadar gulanya tinggi tentu tidak baik memakan yang karbohidratnya tinggi.

Bagi penderita Parkinson tentu tidak baik memakan mentega, keju, susu fullcream, makanan yang terlalu asin, dan makanan tinggi protein karena menghambat kinerja obat (levodopa) masuk ke dalam otak untuk proses seseorang harus tahu tentang dirinya melalui cek laboratorium dan harus mengetahui apa yang ia makan sehat atau tidak untuk dirinya, sesuai atau tidak dengan golongan darahnya. Dengan alasan ini, maka sangat tepat sekali MUI bekerjasama dengan BPOM untuk kesehatan dan kehalalan suatu produk atau makanan. Ketiga, tempatnya atau sanitasi (lingkungan) dimana makanan tersebut berada, apakah steril dari bakteri ataukah tidak. Keempat, makanan tersebut harus jelas masa boleh konsumsinya. Ini bisa dilihat dari bungkus makanan biasanya tertulis tanggal/bulan dan tahun kadarluasanya. Memakan yang sudah basi atau kadarluasa akan menyebabkan sakit perut, mual, pusing, dan bahkan bisa membawa kepada kematian. (Ruslan, 2014: 53-54).

\section{Menghindari Sifat Berlebih-lebihan dalam Konsumsi}

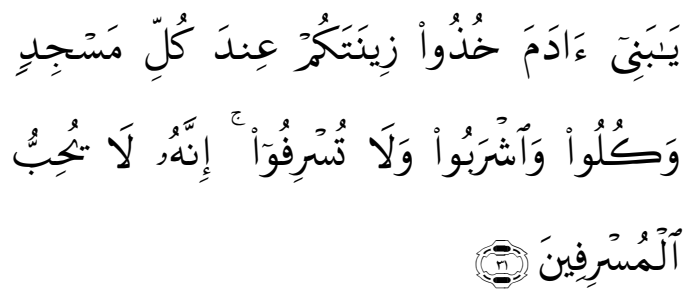


"Hai anak Adam, pakailah pakaianmu yang indah di Setiap (memasuki) mesjid. Makan dan minumlah, dan janganlah berlebih-lebihan. Sesungguhnya Allah tidak menyukai orang-orang yang berlebih-lebihan." (QS. al-A'raf:31)

Kata kunci konsumsi yang terdapat pada ayat ini adalah zînah, kulû, isyrabû dan lâ tusrifû. Menurut Lukman Farouni yang dikutip oleh Azhari Akmal Tarigan, "surat al-A'râf ayat 31-32 turun terkait dengan kejadian beberapa sahabat Nabi yang bermaksud untuk meniru kelompok alHummas yaitu kelompok Quraisy yang menggebu-gebu semangat beragamanya sehingga tidak mau berthawaf kecuali memakai pakaian baru yang belum pernah dipakai melakukan dosa, serta sangat ketat dalam memilih makanan dan kadarnya selama melaksanakan ibadah haji. Jelaslah, ayat tersebut turun sebagai kritik Allah kepada bangsa Quraisy yang berlebih-lebihan dalam beribadah. (Azhari Akmal Tarigan, 2012: 202) Menurut Ibnu Katsir ayat ini diturunkan sebagai penolakan terhadap kebiasaan orang-orang musyrik ketika tawaf tidak memakai pakaian atau dalam keadaan telanjang. (Ibn Katsir,
Yang dimaksud dengan "zînah" di sini ialah al-libâs (pakaian) yang baik, yang bisa menutupi aurat karena menutup aurat hukumnya adalah wajib sebagai syarat sah sholat dan tawaf. Kemudian, diperintahkan juga untuk berindah-indah atau berhias ketika hendak menunaikan sholat, terutama sholat jum'at dan sholat 'ied. (alMaraghiy, T-Th: 8/132) Perintah Allah untuk memakai pakaian yang bagus setiap kali masuk mesjid dalam ayat ini bukanlah dalam pengertian pakaian yang mewah, tetapi pakaian yang suci, wajar, dan menutupi aurat.

Wakulû wasyrabû walâ tusyrifû, makan dan minum dari yang baik-baik lagi halal dan tidak berlebih-lebihan, tetapi harus seimbang dalam mengkonsumsi semuanya, karena Allah pencipta semua nikmat ini tidak menyukai orang-orang yang berlebihlebihan, bahkan Allah akan memberikan hukuman terhadap prilaku yang melampaui batas dan berlebihlebihan sesuai dengan kemudharatan dan kerusakan yang diakibatkan perbuatan tersebut karena menyalahi ketentuan penciptaaan. (al-Maraghiy, T-Th: 8/132) 1999: 3/45) 
Berdasarkan ayat ini, secara ekspilist Allah memerintahkan agar tidak berlebihan atau melampaui batas dalam mengkonsumsi suatu kebutuhan. Artinya, kegiatan konsumsi harus dilakukan secara proporsional. Prinsip ini tentu berbeda dengan ideologi kapitalisme dalam berkonsumsi yang menganggap bahwa konsumsi sebagai suatu mekanisme untuk menggenjot produksi dan pertumbuhan. Semakin banyak permintaan maka semakin banyak pula barang yang diproduksi. Di sinilah kemudian timbul pemerasan, penindasan terhadap buruh agar terus bekerja tanpa mengenal batas waktu guna memenuhi permintaan. Dalam Islam justru berjalan sebaliknya menganjurkan suatu cara konsumsi yang proporsional agar keadilan dan kesetaran untuk semua bisa tercipta (Syaparuddin, 2011).

\section{Menghindari Sifat Boros Dalam} Konsumsi

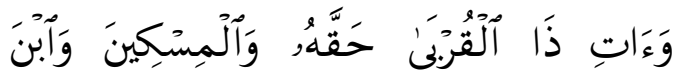

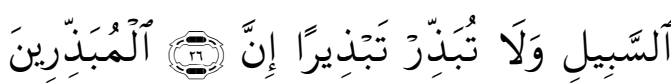

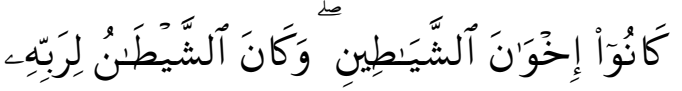
كَفُورًا

"Dan berikanlah kepada keluargakeluarga yang dekat akan haknya, kepada orang miskin dan orang yang dalam perjalanan dan janganlah kamu menghambur-hamburkan (hartamu) secara boros. Sesungguhnya pemboros-pemboros itu adalah saudara-saudara syaitan dan syaitan itu adalah sangat ingkar kepada Tuhannya”. (QS. al-Isrâ': 26-27

Kata kunci konsumsi yang ditunjukkan ayat ini adalah lafazh tubadzdzîr-tabdzîr dan mubadzdzirîn yang bermakna boros.

Sebagian ulama mengatakan ayat ini turun sesuai dengan kebiasaan masyarakat Arab pada waktu itu yang memiliki kebiasaan mengumpulkan harta-harta mereka, kemudian membelanjakannya untuk pamer (secara sombong) dan bermegahmegahan. Orang-orang musyrik dari suku Quraisy dan selainnya mebelanjakan harta mereka untuk menghalangi manusia memeluk Islam dan merendahkan keluarganya serta menolong musuh-musuh Islam, sehingga diturunkanlah ayat ini. (arRaziy, 1981: 20/195)

Secara bahasa tabdzîr (boros) bermakna menyia-nyiakan harta dan membelanjakannya dengan melampaui batas. Menurut Ibnu Mas'ud, at-tabdzîr adalah membelanjakan harta bukan pada jalan yang benar. Pernyataan yang 
sama juga diungkapkan oeh Ibnu untuk pamer. (Afzalurrahman, 1995: Abbas. Pendapat lain dari Mujahid 192)

mengatakan, "seandainya seseorang

Dalam pembahasan sebelumnya membelanjakan semua hartanya dalam kebenaran, maka ia tidak termasuk telah dijelaskan tentang isrâf yang diartikan sebagai berlebih-lebihan atau orang-orang yang berbuat tabdzir melampauai batas. Mubazir (tabdzîr) (pemborosan), namun seandainya ia membelanjakan sedikit saja dari hartanya bukan dalam kebenaran, maka ia termasuk kepada perbuatan tabdzîr (boros). Kemudian Qatadah juga mengatakan, 'tabdzîr adalah membelanjakan harta untuk perbuatan maksiat terhadap Allah, bukan pada sesuatu yang dibenarkan dan terhadap suatu kerusakan. (Ibn Katsir, 1999: 5/69)

Adapun Afzalur Rahman mengungkapkan pemborosan paling tidak mengandung tiga arti. Pertama, membelanjakan harta untuk hal-hal yang diharamkan seperti judi, minuman keras dan lain-lain, apalagi dalam jumlah yang sangat banyak. Kedua, pengeluaran yang berlebih-lebihan untuk barang-barang yang halal baik di dalam maupun di luar batas kemampuan seseorang. Ketiga, pengeluaran untuk tujuan-tujuan amal shaleh tetapi di lakukan semata-mata sering juga dimasukkan ke adalam kategori berlebih-lebihan ini. Namun, ulama bahasa membedakannya meskipun keduanya bersinggungan dalam hal berlebih-lebihan yang tidak pada tempatnya atau melampaui batasan wajar. Dalam kitab al-Furûq al-Lughawiyyah yang dikutip oleh Tim Penulis Tafsir Tematik Kementerian Agama RI dijelaskan beberapa perbedaan antara kedua istilah ini. Term isrâf diartikan sebagai melampaui batas dalam menggunakan harta (تجاوز الحد في صرف المال). Sedangkan at- tabdzîr didefenisiskan sebagai pembelanjaan harta pada halhal yang tidak semestinya, bukan pada tempatnya; lebih tinggi dari pada alisrâf. (إنفاق المال فيما لا ينبغي إتلافه في غير )

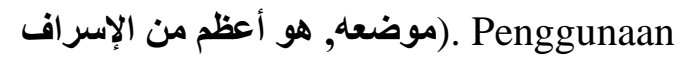
al-isrâf dalam Alquran tidak melulu terkait dengan harta (konsumsi), tetapi segala sesuatu yang ditempatkan tidak pada tempat sewajarnya. Kaum Nabi Luth As. yang menyenangi 
homoseksualitas disebut kaum yang melampaui batas. (Kementerian Agama RI, 2009: 222-223)

Ayat ini melarang manusia bersikap mubazzir (boros), karena sebagai umat Islam tidak seharusnya melakukan pemborosan, sebab kebutuhan hidup yang harus dipenuhi adalah kebutuhan hidup yang cukup. Sesuatu yang dikonsumsi adalah hal yang dibutuhkan, bukan berdasarkan kepada apa yang diinginkan, karena yang dibutuhkan (needs) tidak sebanyak yang diinginkan (wishes), sedangkan yang diinginkan selalu melampaui dana yang dimiliki. Dalam situasi seperti ini kadang kala manusia selalu mencari jalan pintas dengan menghalalkan segala cara untuk mendapatkan apa yang diinginkankannya, meskipun belum tentu ia membutuhkannya. Bisa juga ia membutuhkannya, tetapi sekedar kebutuhan tersier (tahsiniyyât atau kamâliyyât) saja yang bisa ditunda atau dieliminasi sama sekali tanpa menimbulkan kesulitan hidup. Sedangkan pembelanjaan pada yang wajib, mendesak, baik, dan dibutuhkan tentu harus dipenuhi dalam batas-batas kewajaran, sehingga menyebabkan harta menjadi instrumen ujian bagi manusia; sejauh mana dapat dikelola dengan baik sehingga tepat guna dan tepat sasaran sesuai yang dikehendaki Allah Swt.

\section{Menghindari Sifat Pelit/Kikir Dalam Konsumsi}

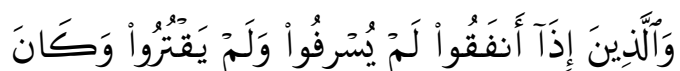

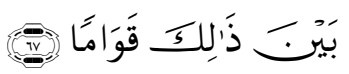

"Dan orang-orang yang apabila membelanjakan (harta), mereka tidak berlebihan, dan tidak (pula) kikir, dan adalah (pembelanjaan itu) di tengahtengah antara yang demikian." (QS. alFurqân:67)

Kata kunci konsumsi dalam ayat ini adalah anfaqû, yaqturû, dan yusrifû. Al-qitr-al-iqtâr-at-taqtîr adalah lawan dari isrâf. Sifat iqtâr (kikir) dan isrâf (berlebih-lebihan) memang dua istilah yang batasannya bersifat relatif, namun perasaan dan pikiran sehat dapat mengenali dan membedakannya dalam kehidupan sehari-hari. Para mufassir menyebutkan beberapa perbedaan antara isrâf dan iqtâr (kikir) dari beberapa segi yaitu: Pertama, merupakan pendapat yang paling kuat mengatakan bahwasannya Allah Swt. mensifati mereka dengan kesederhanaan, yaitu tidak terlalu boros dan juga tidak terlalu hemat. Kedua, al- 
isrâf adalah membelanjakan harta kenyang, maka akan menyebabkan diri untuk perbuatan maksiat terhadap malas untuk beribadah. Ini disebut Allah, sedangkan iqtâr adalah dengan sarf atau isrâf. Namun, jika menghalangi atau mencegah dari hak seseorang makan sesuai dengan Allah Swt. Sebagaimana al-Hasan kebutuhannya, maka ini disebut dengan mengatakan,”janganlah seseorang iqtâr. (ar-Raziy, 1981:24/110) membelanjakan hartanya untuk Dalam Tafsir Tematik yang ditulis perbuatan maksiat kepada Allah dan jangan juga menahannya dari sesuatu yang pantas dan wajar untuknya, karena menahan diri dari hak Allah merupakan perbuatan kikir yang paling parah, meskipun hukumnya tidak sampai wajib, namun ia bisa bermakna sesuatu yang sangat dianjurkan seperti seorang yang kaya yang memiliki banyak harta mengurangi apa yang mesti diinfakkannya terhadap orangorang fakir dari karib kerabatnya. Ketiga, yang dimaksud dengan isrâf adalah melampaui batas dalam menggunakan nikmat yang telah Allah berikan dan hidup dengan berfoya-foya di dunia ini, meskipun itu merupakan sesuatu yang halal. Namun, perbuatan yang demikian merupakan perbuatan yang sangat dibenci karna akan menyebabkan sifat sombong. oleh Kementrian Agama RI disebutkan bahwa secara garis besar sifat kikir dapat dkategorikan menjadi dua: pertama, kikir terhadap sesuatu yang merupakan kewajiban, seperti menolak memberi nafkah terhadap orang yang menjadi tanggungan menurut syar'i, menolak mengeluarkan zakat setelah mencapai nisab dan haul harta. Demikian juga apabila seseorang kikir terhadap pemenuhan kebutuhan primernya. Kedua, kikir terhadap sesuatu yang bukan merupakan kewajiban, seperti menolak memberi sedekah dan sejenisnya kepada orang lain, atau terhadap dirinya sendiri dalam bentuk kebutuhan-kebutuhan sekunder yang wajar. (Kementerian Agama RI, 2009: 237)

Berdasarkan pernyataan di atas, Sedangkan iqtâr bermakna at-tadyîq yang berarti mempersempit atau maka dalam mengkonsumsi harus ada prinsip kesederhanaan dan memperkecil, misal jika makan terlalu seperti ini akan menempatkan 
seseorang pada kondisi yang moderat dalam konsumsi, tidak melakukan konsumsi yang berlebihan dan pemborosan sekaligus tidak menahannahan diri untuk membelanjakan karena kekikiran. Secara hakikat sifat kikir ini berbeda dengan sifat boros dan hidup mewah, akan tetapi ia termasuk sifat yang tercela dalam Islam, karena seseorang tidak menggunakan rezeki dan nikmat yang telah Allah berikan kepadanya untuk dikonsumsi atau digunakan sesuai dengan kadarnya, kebutuhan dan tanggungannya.

Harta yang diakui manusia sebagai hak miliknya pada dasarnya adalah milik Allah yang dikaruniakan kepadanya, sehingga tidak sewajarnya seseorang bersifat kikir terhadap karunia yang telah Allah berikan. Bersifat kikir terhadap diri sendiri maupun orang lain merupakan sifat tercela, akan tetapi berinfak secara berlebih-lebihan dan tidak terkendali juga tidak dianjurkan. Yang baik adalah berada pada posisi tengah yang seimbang (tawâzun), tidak kikir, tidak berlebih-lebihan serta tidak boros. Kemudian, prinsip keseimbangan dalam ayat ini juga berarti memperhatikan keseimbangan antara pengeluaran dan pemasukan. Seorang muslim hendaknya mampu menyeimbangkan antara pemasukan dan pengeluarannya, sehingga seorang akan hidup dalam keseimbangan ekonomi. Selain memperhatikan keseimbangan antara pendapatan dan pengeluaran, penting juga untuk memperhatikan keseimbangan konsumsi lahiriyah dan batiniyah; konsumsi yang bersifat pribadi dengan sosial dan keseimbangan konsumsi dengan kepentingan dunia dan kepentingan akhirat. Keadaan ini merupakan salah satu solusi dari Islam tentang gaya hidup yang seharusnya bagi seorang muslim.

\section{KESIMPULAN}

Berdasarkan pemaparan di atas, Alquran telah memberikan penjelasan detail tentang prinsip-prinsip konsumsi yang sesuai dengan syari'at Islam. Banyaknya ayat yang bercerita tentang konsumsi menunjukkan bahwa Alquran begitu serius membuat aturannya. Alquran bukan hanya bicara masalah bahwa manusia harus mengkonsumsi sesuatu supaya bisa bertahan hidup, tetapi juga menyentuh dimensi lain, yaitu harus mempertimbangkan akibat 
yang ditimbulkan dari cara mengkonsumsi sesuatu.

Pada kasus ini iman mempunyai peranan penting dalam menentukan pola konsumsi, karena mesti ada kontrol spiritual terhadap kepuasan material.

\section{REFERENSI}

Afzalurrahman. 1995. Doktrin Ekonomi Islam. Yogyakarta: Dana Bakti Wakaf.

al-Bukhariy, Muhammad Ibn Isma'il Ibn Ibrahim Ibn alMughirah. 1987. al-Jâmi' alShahîh al-Musnad min Hadîts Rasûlillah Saw. wa Sunanihi wa Ayyâmihi. Kairo: Dâr asy-Syu'ab.

Idri. 2016. Hadis Ekonomi (Ekonomi

Dalam Perspektif Hadis Nabi). Jakarta: Kencana Prenadamedia Grup.

Ibn Katsîr, Ismail Ibn 'Umar. 1999.

Tafsîr al-Qur'ân al-'Azhîm

T.Tp: Dâr Thîbah li an-Nasr wa at-Tauzî’.

Kasdi, A. 2013. Tafsir Ayat-Ayat Konsumsi Dan Implikasinya Terhadap Pengembangan Ekonomi Islam. Equilibrium, 1(Ayat Konsumsi), 18-32. https://doi.org/http://dx.doi.o rg/10.21043/equilibrium.v1i 1.190

Kementrian Agama RI. 2009. Tafsir Tematik: Pembangunan Ekonomi Umat. Jakarta:
Lajnah Pentashih Mushaf alQur'an.

Al-Maraghiy, Ahmad Musthafa. T.Th. Tafsîr al-Marâghiy. Mesir: Syirkah Maktabah wa Mathba'ah Musthafa alBâbiy al-Halabiy.

Al-Qurthubiy, Abu 'Abdullah Muhammad Ibn Ahmad Abu Bakr. 2006. Al-Jâmi' li Ahkâm min al-Qur'ân. Beirut: Mu'assasah arRisâlah.

Al-Qusyairiy, Abu al-Husain Muslaim Ibn al-Hajjaj Ibn Muslim. T.Th. Shahîh Muslim. Beirut: Dâr al-Jîl.

Ar-Râziy, Muhammad Fakhr ad-Dîn. 1981. Tafsîr Fakhr ar-Râziy. Beirut: Dâr al-Fikr.

Ruslan. 2014. Ayat-Ayat Ekonomi (Makna Global dan Komentar). Banjar Masin: IAIN Antasari Press.

Suma, Muhammad Amin. 2013. Tafsir Ayat Ekonomi (Teks, Terjemah, dan Tafsir). Jakarta: Amzah.

Syaparuddin. 2011. Prinsip-prinsip Dasar Al-Qur'an tentang Perilaku Konsumsi. Ulumuna: Jurnal Of Islamic Studies, 15(2), 353-374. https://ulumuna.or.id/index.p $\mathrm{hp} / \mathrm{ujis} /$ article/view/190

Tarigan, Azhari Akmal. 2012. Tafsir Ayat-Ayat Ekonomi Alqur'an (Sebuah Eksplorasi Melalui Kata-Kata Kunci). Bandung: Cita Pustaka Media Perintis. 